\section{UCSF lands a lucky strike}

A California state Superior Court Judge has ruled in favour of academic freedom by upholding a decision by the University of California at San Francisco (UCSF) to release tobacco company documents that reportedly show the industry knew tobacco was a health hazard as early as the 1960s.

Judge Stuart Pollack gave the Brown \& Williamson Company 20 days to file an appeal and told the university to hold distribution of the documents until then.

The decision, furiously fought by the tobacco industry (see Nature Medicine 1, 396-397; 1995), could be a devastating setback for tobacco companies, as they have yet to lose a liability suit brought by smokers. The documents, which allegedly show that the industry patented a critical step in making a safer cigarette and then abandoned the project, could contain powerful ammunition in any future suits.

Four states have sued the tobacco companies to recover the associated health-care costs for smokers. All four Florida, Minnesota, Mississippi and West Virginia - filed papers supporting the university's right to release the documents, as did the American Cancer Society, the American Heart Association and several other health groups.

"I think that because the tobacco industry so vigorously fought the release of these papers, the judge's decision sends a very strong message ... that the people should have access to this information," said Scott Ballin, a spokesperson for the health groups.

The documents were sent to the university and several members of the US Congress by a paralegal in the offices of one of Brown \& Williamson's attorneys. The paralegal, Merrell Williams, was under court order in Kentucky not to distribute copies, but he fled the state and sent out multiple copies with the return address of 'Mr. Butts', an anti-cigarette character in the comic strip 'Doonesbury'.

In reaching his decision, Judge Pollack said that the documents were already widely distributed, Congress has held hearings on their contents, and that it was in the public interest that they be released.

A lawyer for Brown \& Williamson said the company had not decided whether to appeal.

\section{JOEL SHURKIN} San Francisco

\title{
DID YOU KNOW...?
}

\section{Churchill thrived on speed}

It is well known that British Prime Minister Winston Churchill was fond of whiskey, champagne, and brandy. Now, it has come to light that the indomitable prime minister also made what is said to be beneficial use of amphetamines and barbiturates to get through the day and night. In a letter in the 10 June issue of the British Medical Journal, the author of a biography of Churchill's physician (Lord Moran) reveals that Moran routinely prescribed amphetamines when Churchill was troubled by 'muzzy feelings' after a stroke in 1953 and 'reds' or Seconal $(100 \mathrm{mg})$ when he needed sleep after a full day's drinking.

According to biographer Richard Lovell, Moran had an armamentarium of 'majors' (Drinamyl tablets containing $d$-amphetamine sulphate $5 \mathrm{mg}$ and amylbarbitone $32 \mathrm{mg}$ ) and 'minors' (Edrisal tablets combining $160 \mathrm{mg}$ aspirin, $160 \mathrm{mg}$ phenacetin and $25 \mathrm{mg}$ amphetamine sulphate).

It seems highly unlikely that doctors today would knowingly prescribe uppers and downers for someone with a sturdy appetite for drink but some British physicians who have read Lovell's revealing letter are quoted in the Times of London as saying that there may be an old lesson for new research here.

B.J.C.

A new look at 'traditional' medicine Indian Prime Minister P. V. Narasimha Rao announced in late May plans to set up a new department of Indian systems of medicine "to further develop and encourage the ancient and indigenous system of health care." In the past, these systems of medicine, of which Ayurveda (more than

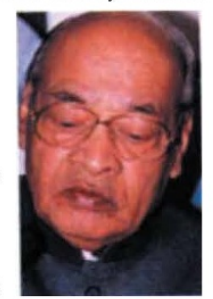
2,500 years old), Siddha and Unani are the most popular, were largely uncoordinated.

The formation of this new department within the Ministry of Health and Family Welfare, for which the government has set aside US\$36 million, is also part of an effort to integrate more effectively the ancient and modern systems of medicine.

It is estimated that in India about 400,000 trained and untrained doctors use some form of 'traditional' medicine and that between 50 and 60 per cent of Indians utilize the services of traditional doctors.

\section{K. S. JAYARAMAN} New Delhi
Eyeing up 'e-journals'

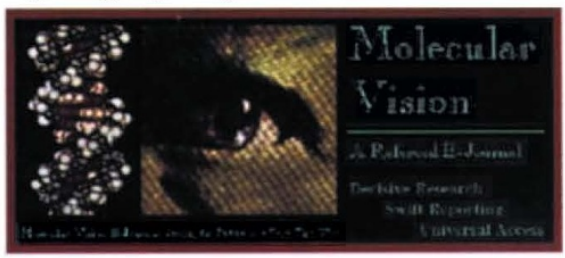

At the May meeting of the Association for Research in Vision and Ophthalmology, the creation of Molecular Vision, yet another new peer-reviewed journal, was announced. But Molecular Vision will never be mailed, stacked in a library, carried around or become dogeared. It is one of nearly 100 peer-reviewed journals now published on the World Wide Web (WWW), part of the Internet.

Although Molecular Vision is not the first electronic journal (or 'e-journal', the preferred term of the literati), it is one of the first with a biomedical focus to take advantage of the new capabilities offered by the $\mathrm{WWW}$. These include the elapsed time between acceptance and publication (virtually none), subscription costs (currently nothing) and access (anyone with a computer). But the ease of use and access have drawbacks, most notably the daunting task of centrally referencing what is likely to be an explosion of biomedical e-journals. Molecular Vision can be found at:

http://umw.cc.emory.edu/MOLECULAR_VISION/index.html

F.R.S

\section{Japan jumps on the gene} therapy bandwaggon

Five hundred people attended the first annual meeting of the Japanese Society for Gene Therapy, held in late May in Tokyo. Presentations were given on subjects ranging from gene transfer techniques to gene therapy of cancer. Researchers at Hokkaido University presented a report on Japan's forthcoming first gene therapy trial.

Fumimaro Takaku, president of the society, which currently has its secretariat at the Department of Hematology-Oncology at the University of Tokyo, acknowledges that Japan lags behind the United States and Europe in gene therapy, but hopes that the new society will encourage young Japanese researchers to move into this field. He also hopes that Japanese researchers will forge links with those from other countries; there are already plans to invite foreign researchers to next year's meeting to be held at the University of Tokyo in May. RICHARD NATHAN Tokyo 